Article

\title{
Tree Roots Anchoring and Binding Soil: Reducing Landslide Risk in Indonesian Agroforestry
}

\author{
Kurniatun Hairiah ${ }^{1, *}$, Widianto Widianto ${ }^{1}$, Didik Suprayogo ${ }^{1}$ and Meine Van Noordwijk ${ }^{1,2,3}$ (i) \\ 1 Faculty of Agriculture, Brawijaya University, Jl Veteran, Malang 65145, Indonesia; \\ widianto@gmail.com (W.W.); suprayogo@ub.ac.id (D.S.); m.vannoordwijk@cgiar.org (M.V.N.) \\ 2 World Agroforestry (ICRAF), Bogor 16155, Indonesia \\ 3 Plant Production Systems, Wageningen University \& Research, 6700 AK Wageningen, The Netherlands \\ * Correspondence: kurniatun_h@ub.ac.id or k.hairiah@cgiar.org
}

Received: 30 June 2020; Accepted: 30 July 2020; Published: 1 August 2020

\begin{abstract}
Tree root systems stabilize hillslopes and riverbanks, reducing landslide risk, but related data for the humid tropics are scarce. We tested fractal allometry hypotheses on differences in the vertical and horizontal distribution of roots of trees commonly found in agroforestry systems and on shear strength of soil in relation to root length density in the topsoil. Proximal roots of 685 trees (55 species; 4-20 cm stem diameter at breast height, dbh) were observed across six landscapes in Indonesia. The Index of Root Anchoring (IRA) and the Index of Root Binding (IRB) were calculated as $\Sigma \mathrm{D}_{\mathrm{v}}{ }^{2} / \mathrm{dbh}^{2}$ and as $\Sigma D_{h}{ }^{2} / \mathrm{dbh}^{2}$, respectively, where $D_{v}$ and $D_{h}$ are the diameters of vertical (angle $>45^{\circ}$ ) and horizontal (angle $<45^{\circ}$ ) proximal roots. High IRA values $(>1.0)$ were observed in coffee and several common shade trees. Common fruit trees in coffee agroforestry had low medium values, indicating modest 'soil anchoring'. Where root length density $\left(\mathrm{L}_{\mathrm{rv}}\right)$ in the topsoil is less than $10 \mathrm{~km} \mathrm{~m}^{-3}$ shear strength largely depends on texture; for $\mathrm{L}_{\mathrm{rv}}>10$ shear strength was $>1.5 \mathrm{~kg} \mathrm{~m}^{-2}$ at the texture tested. In conclusion, a mix of tree species with deep roots and grasses with intense fine roots provides the highest hillslope and riverbank stability.
\end{abstract}

Keywords: coffee; fruit trees; index of root anchoring; slope stability; soil shear strength; root length density; root tensile strength

\section{Introduction}

Watersheds usually provide water but occasionally they generate mudflows. Intense seasonal precipitation during monsoons in mountainous watersheds can trigger landslides, debris flows, and flash floods. On steep slopes, landslides can destroy houses, villages, or any vegetation encountered in the downhill path. Soil and debris flow can also be a major contributor of sediment load in the river systems. Extreme rainfall events generate shallow slope failures by elevating pore pressures and decreasing effective stress, but numerous site-specific factors, such as preferential hydrologic flow paths, slope steepness, soil thickness, and existing plants root systems influence the potential for slope instability [1,2]. Agroforestry can reduce risks by having appropriate trees (species, age, diversity, management) at strategic locations at hillslope and landscape scale [3]. Higher plant diversity was found [4] to enhance soil stability in disturbed alpine ecosystems.

Shear strength is a term used in soil mechanics to describe the resistance against structural failure, or the magnitude of the shear stress that a soil can sustain before submitting to a sliding failure along a plane that is parallel to the direction of the force. The shear resistance of soil is a result of friction and interlocking of particles, and possibly cementation or bonding at particle contacts, strengthened by roots depending on their tensile strength. Tensile strength is a measure of the force required to pull something such as rope, wire, or a structural beam to the point where it breaks. Soil shear strength of 
rooted soil $s_{r}$ exceeds that of unrooted soil $s$ according to $\mathrm{s}_{\mathrm{r}}=\mathrm{s}+1.2 \sum \mathrm{T}_{\mathrm{a}}$, where $\mathrm{T}_{\mathrm{a}}$ it the tensile strength per unit cross-sectional area of all roots at the plane sheared. The factor 1.2 is an approximation derived for common slope angles [5]. A review of experimental methods and procedures to test root-strength and rooted-soil shear-strength behavior, focused on obtaining data to parameterize root reinforcement models. [6]. Common methods either determine the tensile strength of individual roots by loading the root in a pulling device until it breaks or determine the shear-strength of rooted soil in comparison to non-rooted soil in a Coulomb-type shear-box test. Laboratory shear-box tests encounter a difficulty in that the roots are not generally fixed or constrained at the base of the shear-box and are pulled rather than break.

The mechanics of 'failure' are broadly understood in terms of weight of the (wet) soil plus vegetation, slope, and critical soil shear strength. A higher soil clay content and lower water content lead to higher soil shear strength [7-9]. Intensifying soil management after forest conversion can lead to soil compaction meaning lower pore space and soil infiltration, enhancing shear strength and overland flow; along with a reduction of the weight of the vegetation such changes can reduce the chances of slope failure with time after forest conversion [10]. However, loss of 'root anchoring' associated with gradual decay of tree roots in the first few years after conversion will enhance the risk of landslides [11,12]. Conversion affecting only part of a hill slope, e.g., by road construction, can modify subsurface flows, leading to concentrated flows and locally enhanced landslide risk. The deepest and most destructive landslides, however, may be hardly influenced by vegetation. Still, a combination of deep-rooted trees for anchoring and shallow rooted grass (for stabilizing topsoil) is hypothesized to stabilize slopes prone to mass movement. At least four system levels are involved: the vegetation (species, stem diameters, spatial distribution of trees), the distribution of roots of an individual tree over the soil profile (shoot/root allometry, vertical root distribution), the effects of root length density on soil shear strength throughout the profile (it is the weakest plane on which the soil will shear), and the tensile strength of roots determining when individual roots will break. Most studies focus on only part of this range of scales.

Several studies on how woody species, mostly planted forests, influence slope stability have been reported in temperate areas such as Alaska [13,14], Canada [15], China [16-18], New Zealand [19], Australia [20], and the Mediterranean region [21,22]. A study in Australia [23] quantified increases in soil strength due to root reinforcement, on the basis of root strength, interface friction between the roots and the soil, and the distribution of roots within the soil for two common riparian species: river red gum (Eucalyptus camaldulensis) and swamp paperbark (Melaleuca ericifolia). They found that interspecies differences in the strength of living roots had less significance for bank reinforcement than interspecies differences in root distribution. A study in New Zealand found that shear strength contributions per tree did not differ between the native kanuka tree (Kunzea ericoides) and the species replacing it (Pinus radiata) on hillslopes prone to storm-generated land sliding, but higher stand density explained a slope protection advantage of the native vegetation [24]. A comparison between 9, 20, and 30-year-old stands of Cryptomeria japonica stands in China found that root density was highest in the 9-year-old stand, but that root tensile strength was lowest at this stage. As older stands had been thinned, however, the 9-year old stands contributed most to slope stability [25]. A study in Italy with three local shrub species found that these complement each other in different parts of the landscape in stabilizing steep hillslopes which are seasonally affected by storm-induced shallow landslides, by anchoring into the soil mantle. Root tensile force, at which a root breaks, increased with increasing root diameter, but tensile strength (per unit cross-sectional area) decreased with increasing root diameter following a power law curve [26]. Other studies found that when root distribution has a wide range of diameters, the root reinforcement results are controlled by large roots, which hold much more force than small roots [27].

Measurements from tropical vegetation, with higher tree diversity, on shear strength in relation to tree properties are scarce, however [28]. Interspecific variation in root strength in the tropics remains largely undescribed, with the exception of a study in southern Thailand [29] that compared roots of seven tree species in their effects on slope stabilization in the context of biotechnical slope protection. 
The coarse root system of trees may differ in mixtures from that in monocultures [30], with shorter, more dense roots in focal trees growing with conspecific neighbors. A three-dimensional view on tree coarse roots is needed to verify this [31].

The mechanical effect of root systems in enhancing soil stability is based on at least three mechanisms [32]: (a) fine root systems in the surface layers bind soil particle strongly increasing cohesion [33]; through the more stable soil structure they reduce the entrainment of soil particles in overland flow of water; (b) the tensile strength of roots in the surface layers enhance shear strength and the risks that small blocks of soil break away on river banks, roadsides, gullies, or natural channels; (c) deep tree root systems support tree trunks and act as an anchor to the soil [34] resulting in a high root resistance to storm force and reducing the chance that larger soil masses are flushed away once channels are formed. Depending on the relative importance of those mechanisms, the choice of vegetation and its associated rooting pattern can influence slope stability. The susceptibility of cut slopes to land sliding can under certain circumstances be increased rather than reduced by the establishment of a vegetation cover, if the increase in infiltration rate offsets the mechanical benefits of soil reinforcement by roots.

Not all tree roots are the same. A study of 10 European perennials [35] found that root tensile strength-diameter relationships depend strongly on taxa. Root characteristics including root length density, diameter, lignin, and polyphenolic content are known to affect the soil cohesion [36]. Lignin content of wood is the primary determinant of strength, but also affects the rate of decomposition [18]. The role of polyphenolics and protein (linked to $\mathrm{N}$ content) is less clear in root strength, but these factors certainly influence the rate of decomposition and hence decay rate of strength of dead roots [37-39]. Root tensile strength, which is supposedly an intrinsic property that does not depend on the dimensions of the test specimen, can increase with decreasing root diameter, associated with a higher percentage of cellulose [40]. While trees differ in their spatial distribution of woody roots over the soil profile, their branching pattern generally adheres to fractal branching rules and allometric relations on the basis of proximal root diameters at the stem base can be used to predict total size of a root system, similar to the allometric equations that relate aboveground biomass to stem diameter [41,42].

Scaling up from a bundle of roots to tree stands [43] needs to consider counteracting processes. Tree roots not only influence tensile strength that reduces, but also infiltration and subsurface flows that contribute to landslide risk [44]. In the context of a broad evaluation of the role of agroforestry in maintaining or restoring watershed functions in the humid tropics [45], we tested hypotheses at four scales (individual) woody roots, rooted volumes of soil, tree root systems, and riparian vegetation:

1. The critical load where individual roots break is related to the root's lignin content,

2. The shear strength of a volume of soil increases proportionally to the number and strength of individual roots,

3. With a similar overall ratio of woody root to stem cross sectional area, there are consistent differences between tree species in root development in the topsoil and at depth, that contribute to differences in soil binding and soil anchoring, respectively,

4. Differences in the distribution of tree roots between species can be used to reduce landslide risks in the context of productive coffee agroforestry systems.

\section{Materials and Methods}

\subsection{Location}

The research was carried out in six sites: (a) Waybesai watershed, Sumberjaya (W. Lampung), (b) Ciherang and Cibadak sub-watershed, Sentul (West Java), (c) Kalikonto sub-watershed, Pujon and Ngantang-Malang (East java), (d) the UB-forest on the slopes of the Arjuna mountain (Malang), (e) Bangsri watershed Wajak-Malang (East java), (f) Upper Bedadung watershed, Jember, (East Java) (Figure 1 and Table 1). The measurements were performed in three steps: (a) individual root strength 
in relation to root properties; (b) root length density in relation to soil shear strength in the surface layer in Sumberjaya, West Lampung; (c) inventory of the potential of tree root systems as an anchor to maintain hillslope and river bank stability in all six sites.

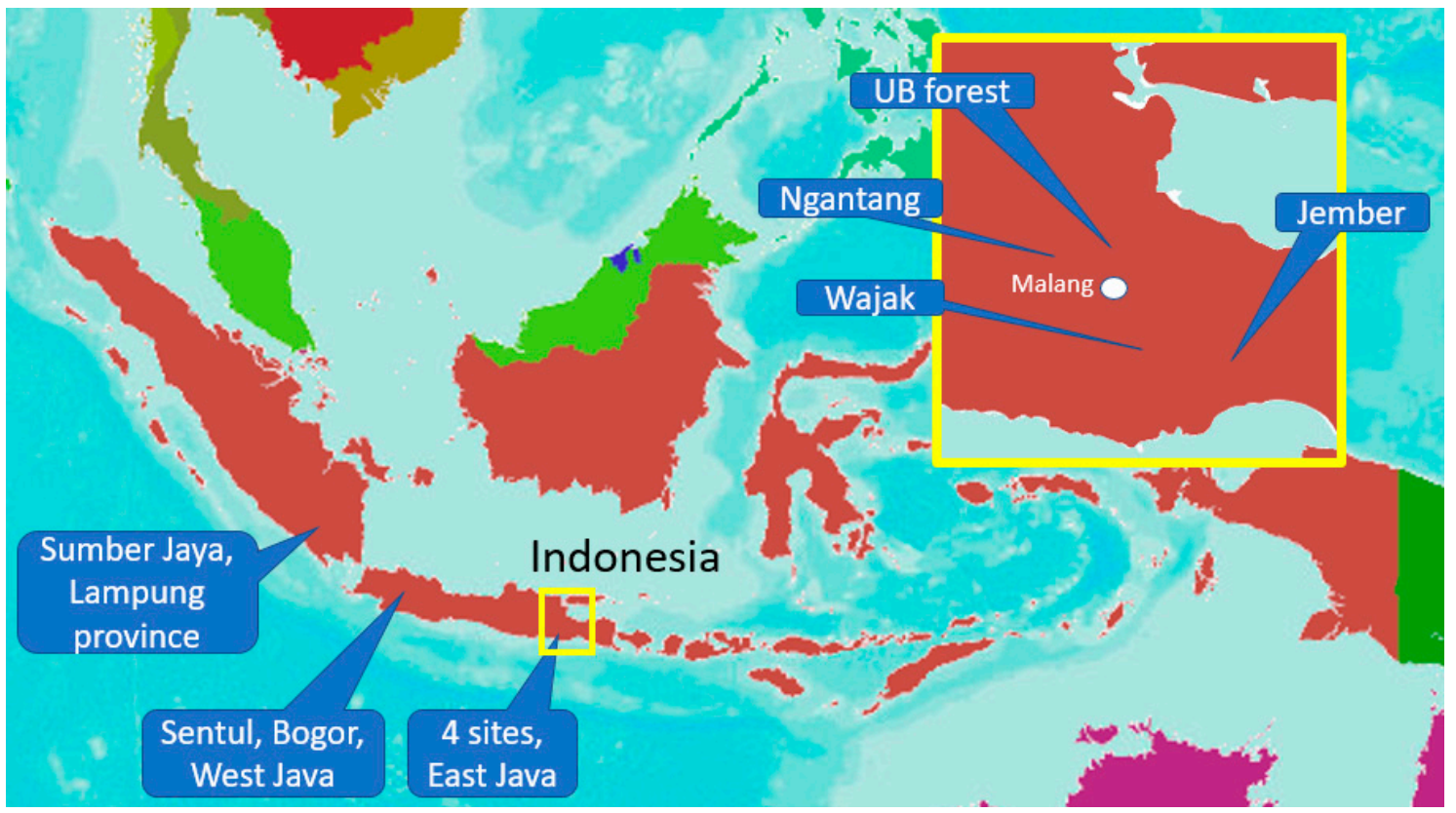

Figure 1. Location of six study sites in East Java, West Java, and Sumatra.

Table 1. Geoposition and characteristics of five study sites.

\begin{tabular}{|c|c|c|c|c|c|}
\hline $\begin{array}{l}\text { Watershed and } \\
\text { Time of Study }\end{array}$ & Geoposition & $\begin{array}{l}\text { Altitude, } m \text { above } \\
\text { Sea Level }\end{array}$ & $\begin{array}{c}\text { Annual } \\
\text { Rainfall, mm }\end{array}$ & Soil Type & Main Tree Crops \\
\hline $\begin{array}{l}\text { Way Besai, Sumber } \\
\text { Jaya, West Lampung, } \\
\text { (2005-2006) }\end{array}$ & $\begin{array}{c}5^{\circ} 01^{\prime} 29.9^{\prime \prime}-5^{\circ} 02^{\prime} 34.2^{\prime \prime} \mathrm{S} \\
104^{\circ} 25^{\prime} 46.5^{\prime \prime}-104^{\circ} 26^{\prime} 51.4^{\prime \prime} \mathrm{E}\end{array}$ & $700-1700$ & $2500-2614$ & $\begin{array}{l}\text { Inceptisol and } \\
\text { Andisols }\end{array}$ & $\begin{array}{c}\text { Coffea, Gliricidia, } \\
\text { Persea, Durio, } \\
\text { Artocarpus, Aleurites }\end{array}$ \\
\hline $\begin{array}{c}\text { Ciherang and } \\
\text { Cibadak } \\
\text { sub-watershed, } \\
\text { Sentul Bogor, } \\
\text { West Java (2007) }\end{array}$ & $\begin{array}{c}6^{\circ} 35^{\prime} 37^{\prime \prime}-6^{\circ} 35^{\prime} 29^{\prime \prime} \mathrm{S}, \\
106^{\circ} 54^{\prime} 58^{\prime \prime}-106^{\circ} 55^{\prime} 47^{\prime \prime} \mathrm{E}\end{array}$ & 1529 & 4000 & Inceptisol & $\begin{array}{l}\text { Maesopsis, Pangium, } \\
\text { Eugenia, Sandoricum }\end{array}$ \\
\hline $\begin{array}{c}\text { Kali Konto } \\
\text { sub-watershed } \\
\text { (Pujon and Ngantang } \\
\text { village), Malang, } \\
\text { East Java (2006-2007) }\end{array}$ & $\begin{array}{c}7^{\circ} 46^{\prime} 03^{\prime \prime}-7^{\circ} 56^{\prime} 54^{\prime \prime} \mathrm{S}, \\
112^{\circ} 19^{\prime} 20^{\prime \prime}-112^{\circ} 29^{\prime} 55^{\prime \prime} \mathrm{E} .\end{array}$ & 1150 & $1797-3151$ & Inceptisol & $\begin{array}{c}\text { Coffea, Durio, Persea, } \\
\text { Gliricidia, Pinus, } \\
\text { Maesopsis, Toona, } \\
\text { Agathis }\end{array}$ \\
\hline $\begin{array}{c}\text { Kalisari } \\
\text { sub-watershed } \\
\text { (UB Forest), Malang, } \\
\text { East Java (2019) }\end{array}$ & $\begin{array}{c}7^{\circ} 49^{\prime} 30^{\prime \prime}-7^{\circ} 51^{\prime} 36^{\prime \prime} \mathrm{S}, \\
112^{\circ} 34^{\prime} 38^{\prime \prime}-112^{\circ} 36^{\prime} 53^{\prime \prime} \mathrm{E}\end{array}$ & 900-1300 & 2005 & $\begin{array}{l}\text { Inceptisol, } \\
\text { Andisol }\end{array}$ & $\begin{array}{c}\text { Pinus, Swietenia, } \\
\text { Coffea, Gliricidia, } \\
\text { Calliandra, Hibiscus, } \\
\text { Parkia, Toona, } \\
\text { Erythrina }\end{array}$ \\
\hline $\begin{array}{c}\text { Bangsri } \\
\text { sub-watershed, } \\
\text { Wajak, Malang, East } \\
\text { Java (2018) }\end{array}$ & $\begin{array}{c}8^{\circ} 7^{\prime} 29^{\prime \prime}-8^{\circ} 7^{\prime} 32^{\prime \prime} \mathrm{S}, \\
112^{\circ} 47^{\prime} 30^{\prime \prime}-112^{\circ} 48^{\prime} 30^{\prime \prime} \mathrm{E}\end{array}$ & $660-720$ & $2220-2314$ & $\begin{array}{l}\text { Inceptisol, } \\
\text { Entisol }\end{array}$ & $\begin{array}{l}\text { Persea, Durio, } \\
\text { Paraserianthes, } \\
\text { Swietenia, Pinus, } \\
\text { Michelia }\end{array}$ \\
\hline $\begin{array}{c}\text { Upper Bedadung } \\
\text { watershed, Jember, } \\
\text { East Java (2006) }\end{array}$ & $\begin{array}{l}7^{\circ} 59^{\prime} 66^{\prime \prime}-8^{\circ} 33^{\prime} 56^{\prime \prime} \mathrm{S}, \\
113^{\circ} 19^{\prime}-114^{\circ} 02^{\prime} 30^{\prime \prime} \mathrm{E},\end{array}$ & $300-3000$ & 2699 & $\begin{array}{l}\text { Inceptisol and } \\
\text { Andisols }\end{array}$ & $\begin{array}{l}\text { Coffea, Leucaena, } \\
\text { Swietenia, Hevea, } \\
\text { Ochroma, }\end{array}$ \\
\hline
\end{tabular}

\subsection{Individual Root Strength in Relation to Root Properties}

Root strength, the tensile force per unit area of root needed to break the root, was measured by clamping a weight onto a vertically hanging root and increasing the downward force until rupture. A tensile strength apparatus [46,47] was developed locally. Five tree species (all 5 years old) were selected for this study: mahogany (Swietenia mahogani), gmelina (Gmelina arborea), suren (Toona sureni), coffee (Coffea canephora), and bamboo (Bambusa arundinacea). Root samples were collected from three 
trees of each species from farmers' plots in Singosari village (Malang). Fresh roots with a length of about $25 \mathrm{~cm}$ and a diameter of close to $2 \mathrm{~mm}$ were placed in the tensile strength apparatus. The mean of six replicate root measurements of the force required to shear the root was used as indicator of root strength. A composite dry root sample of about $10 \mathrm{~g}$ from each species was used for analysis of chemical root characteristics: total carbon content $C$ measured with the wet oxidation method of Walkley and Black [48], total nitrogen content (N) measured using the Kjeldahl distillation method, concentration of lignin by boiling plant sample with a sulfuric acid solution of Cetrimethyl Ammonium Bromide (CTAB) under controlled temperature [49], and polyphenolics by extracting plant tissues with methanol and subsequently colorimetrically measuring absorbance at a wavelength of $760 \mathrm{~nm}$ by the Folin-Denis method [50].

\subsection{Role of Root Length Density in Soil Shear Strength}

Roots add shear strength to soil when the root network penetrates a potential failure surface. The amount of tensile root force contributed to a potential slide mass should increase with increasing area of root intersection. Hence, we explored how soil shear strength was related to the root length density $\left(\mathrm{L}_{\mathrm{rv}}\right)$ at different distances to tree trunks. Tree roots can increase the shear strength of shallow soils through mechanical reinforcement [9].

Measurement on tree root length density was done in two study sites, focused on coffee (Coffea canephora) and shade tree species commonly grown in coffee agroforestry system of each site. In Sumberjaya, root measurements thus included coffee (Coffea canephora), Gliricidia sepium ('kayu hujan'), Maesopsis eminii ('pohon afrika'), Artocarpus heterophyllus (jackfruit), and Bambusa arundinacea (bamboo), and mixed 'fallow vegetation' (dominated by Trema orientalis and Melastoma; local names are, respectively, 'anggrung' and 'harendong') and the edges of rice fields. In Malang, the measurement was performed on five tree species i.e., Coffea canephora (coffee) and Bambusa arundinacea (bamboo), Swietenia mahogany (mahogany), Gmelina arborea (gmelina), Toona sureni (suren). The trees selected for measurements were 5 years old, with three replications.

Soil and root samples were taken using two PVC rings of $5 \mathrm{~cm}$ height and $10 \mathrm{~cm}$ in diameter, temporarily connected, for measuring soil shear strength (Figure 2; [51]), and subsequently root length density. Soil and root samples were taken from the topsoil layer of 0-10 cm, at different distances to trees i.e., 50, 100, 150, $200 \mathrm{~cm}$ to obtain variation in root length density. For rice, samples were taken along a bund at $0-5 \mathrm{~cm}$ soil depth. Soil shear strength was measured by holding the lower and pulling the upper ring, recording the weight that had to be added to cause a break between the two rings. Soil texture and soil bulk density were measured in these same samples using the pipette and gravimetric technique. Subsequently, roots were separated from the soil by wet sieving. Roots of selected trees were separated from other roots of different crops. Root length density $\left(\mathrm{L}_{\mathrm{rv}}\right)$ was measured using the line intersect method [52] on washed soil samples. Root samples were dried in the oven at $80^{\circ} \mathrm{C}$ for $48 \mathrm{~h}$ to estimate their dry weight $\left(\mathrm{D}_{\mathrm{rv}}\right)$. The GENSTAT 8.0 software [53] was used to carry out ANOVA (analysis of variance) including a $t$-test to separate means. 


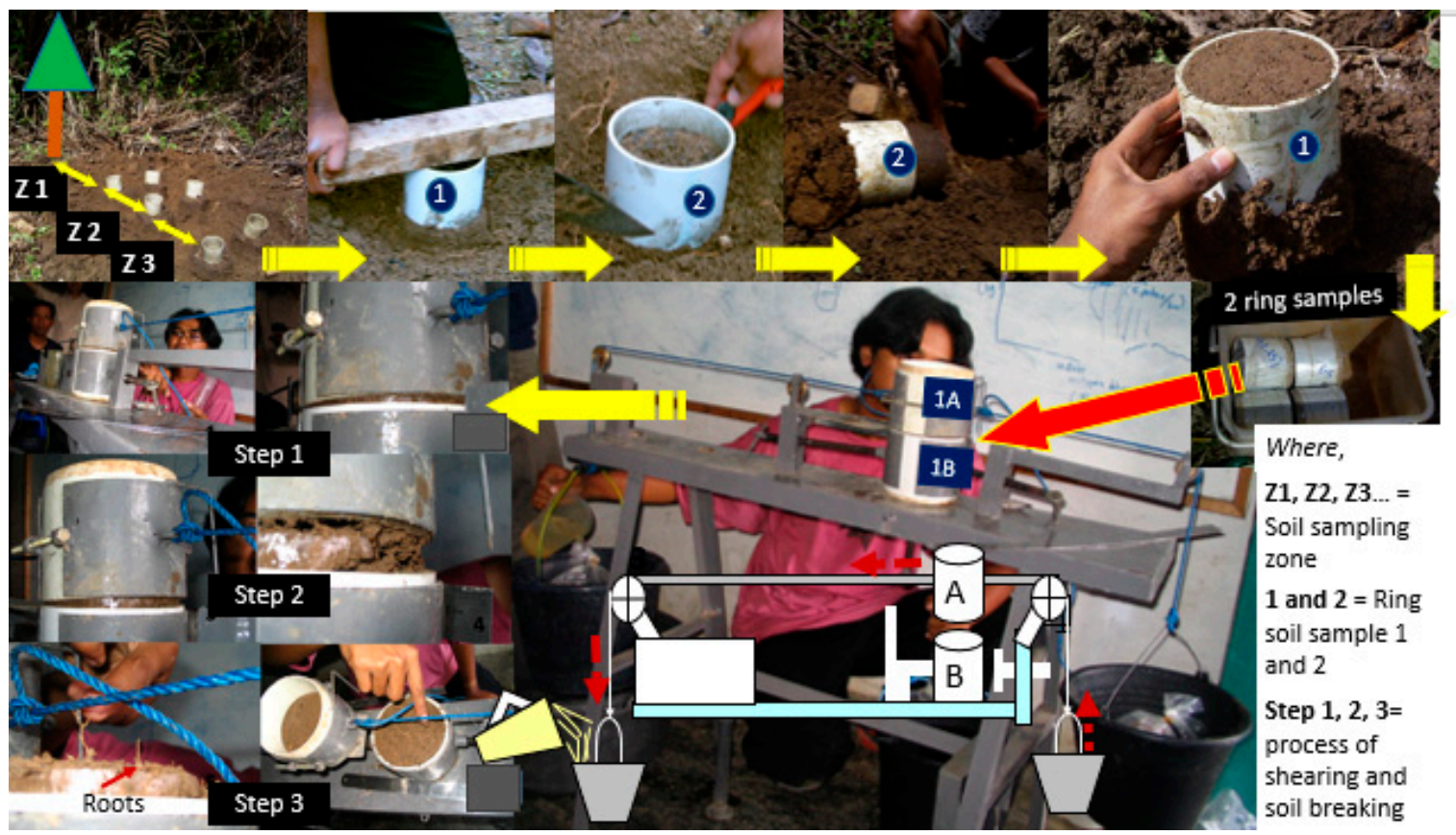

Figure 2. Taking soil samples in the study site in a double ring and measuring soil shear resistance by increasing the pull by adding water to a bucket until the upper ring moves.

\subsection{Inventory of Potential Tree Root System as an Anchor to Maintain Slope and Riverbank Stability}

At each of the six sites saplings $(<5 \mathrm{~cm}$ dbh) and trees $(>5 \mathrm{~cm} \mathrm{dbh})$ of common trees species were selected in multistrata coffee and other agroforestry systems, with a minimum age of 5 years (according to local farmer assessment). High economic value trees were prioritized for the observations and compared to bush fallow vegetation. Proximal roots (close to the tree stem) were exposed [41], with their diameter measured at 20-30 from the trunk, classified as either 'horizontal' or 'vertical' (using an angle of $45^{\circ}$ as threshold; Figure 3). Two root indices were calculated i.e., Index of Root Anchoring (IRA) and Index of Root Binding of Soil (IRB). IRA was calculated as $\Sigma \mathrm{D}_{\mathrm{v}}{ }^{2} / \mathrm{dbh}^{2}$ where dbh is tree diameter at breast height $(1.3 \mathrm{~m}$ height $)$ and $\mathrm{D}_{\mathrm{v}}$ is the diameter of vertical roots [54,55]; IRB was calculated as $\Sigma \mathrm{D}_{\mathrm{h}}{ }^{2} / \mathrm{dbh}^{2}$, where $\mathrm{D}_{\mathrm{h}}$ is diameter of horizontal roots. Some vertical roots were sampled for measurement of wood density, lignin content, and polyphenolic content using the same method as described in Section 2.2. 


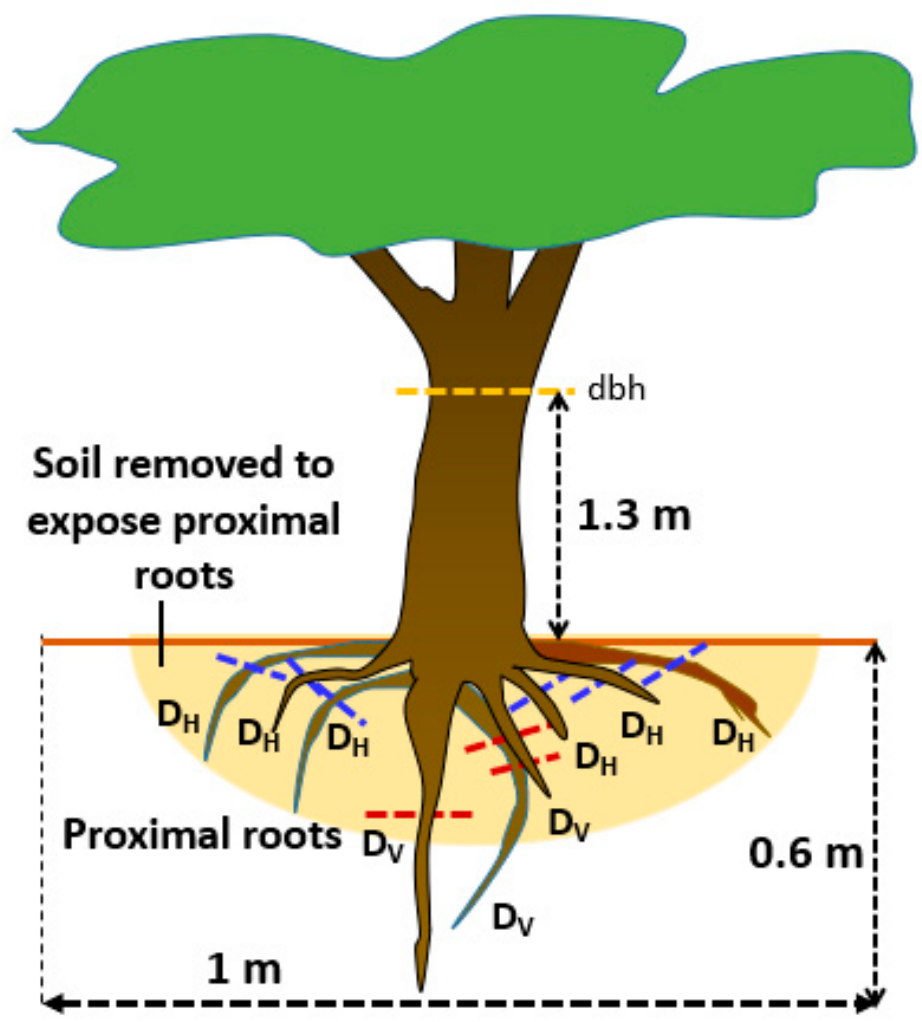

Figure 3. Schematic diagram of the distribution of proximal roots [41]; horizontal $(\mathrm{H})$ roots descend at an angle of $<45^{\circ}$, vertical $(\mathrm{V})$ roots descend at an angle of $>45^{\circ} ; \mathrm{D}=$ root diameter; $\mathrm{dbh}=$ diameter at breast height.

\section{Results}

\subsection{Individual Root Strength in Relation to Root Properties}

Tree roots of approximately $2 \mathrm{~mm}$ in diameter (fine roots) were found to break when a weight of 2-15 kg was applied, which corresponds with $64-478 \mathrm{kPa}\left(\mathrm{kg} \mathrm{cm}^{-2}\right)$ or $0.06-0.48 \mathrm{MPa}$ of root tensile strength. There was considerable variation in lignin content of the roots $(13-30 \%$, with high contents in mahogany and coffee; Table 2) and this was associated with root tensile strength (Figure 4A). About $70 \%$ of the variation in root strength was associated with variation in lignin content. The ratio of (Lignin + Polyphenol)/N that generally associate with decomposition rate [38] had less predictive power on root strength than lignin content alone. A multiple regression shows that root strength was positively related with the $\mathrm{N}$ content, but negatively with the polyphenol content, with about $80 \%$ of variation accounted for (Figure 4B).

Table 2. Chemical characteristics of tree root system.

\begin{tabular}{ccccccc}
\hline Litter Type & $\mathbf{N ~ ( \% )}$ & L (\%) & $\mathbf{P ~ ( \% )}$ & L/N & P/N & (L + P)/N \\
\hline Mahogany & 0.6 & 29.2 & 26.4 & 45.0 & 40.7 & 85.7 \\
Toona & 1.2 & 18.9 & 7.7 & 16.4 & 6.7 & 23.1 \\
Gmelina & 1.3 & 13.5 & 8.1 & 10.1 & 6.0 & 16.1 \\
Coffea & 5.4 & 20.1 & 5.4 & 3.7 & 1.0 & 4.7 \\
Bamboo & 1.0 & 16.0 & 1.6 & 16.5 & 1.6 & 18.2 \\
\hline
\end{tabular}

$\mathrm{N}$ : total nitrogen content, L: lignin content, P: polyphenol content. 
(A)

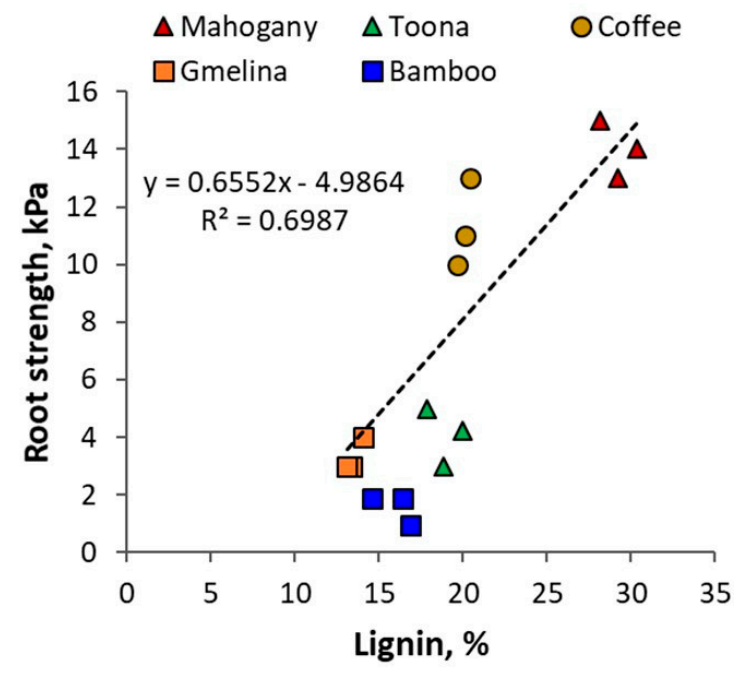

(B)

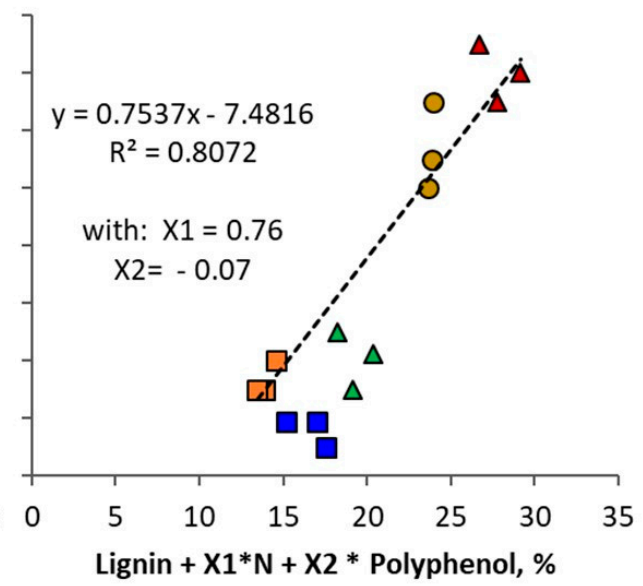

Figure 4. Regression of root tensile strength on (A) lignin content and (B) a linear combination of lignin content $\mathrm{L}$, nitrogen content $\mathrm{N}$, and polyphenol content $\mathrm{P}$.

\subsection{Tree Root Length Density ( $\left.L_{r v}\right)$}

Figure $5 \mathrm{~A}$ shows root length density, $\mathrm{L}_{\mathrm{rv}}\left(\mathrm{km} \mathrm{m}^{-3}\right)$ in the topsoil layer of $0-10 \mathrm{~cm}$ for different tree species with ages of 3, 5, and 7 years old. The average $\mathrm{L}_{\mathrm{rv}}$ for coffee, Gliricidia, Maesopsis, and Artocarpus was $2.9,1.4,2.7$, and $1.7 \mathrm{~km} \mathrm{~m}^{-3}$, respectively. Statistical analysis revealed a significant $(p<0.05)$ interaction between tree species and age. Root length density of coffee was lower at 7 than at 5 years of age, probably affected by tree pruning regimes after the peak coffee harvest years around 5 years of age. The highest $\mathrm{L}_{\mathrm{rv}}$ was found in 5 -year-old coffee $\left(6.5 \mathrm{~km} \mathrm{~m}^{-3}\right)$. At 7 years, Maesopsis and jackfruit had a $\mathrm{L}_{\mathrm{rv}}$ of about $2.1 \mathrm{~km} \mathrm{~m}^{-3}$ significantly $(p<0.05)$ higher than that in 7-year old coffee and Gliricidia. The lowest $\mathrm{L}_{\mathrm{rv}}$ was found in 3-year-old Gliricidia $\left(1.2 \mathrm{~km} \mathrm{~m}^{-3}\right)$. In comparison to non-tree species i.e., bamboo and shrubs (about 3-5 years) and rice, the trees tested here had about $80 \%$ lower $\mathrm{L}_{\mathrm{rv}}$ than nontree (average $10 \mathrm{~km} \mathrm{~m}^{-3}$ ). Bamboo has the highest $\mathrm{L}_{\mathrm{rv}}$, with about $14.6 \mathrm{~km} \mathrm{~m}^{-3}$ followed by mixed shrub vegetation $\left(10 \mathrm{~km} \mathrm{~m}^{-3}\right)$ and rice $\left(5.6 \mathrm{~km} \mathrm{~m}^{-3}\right)$.

(A)

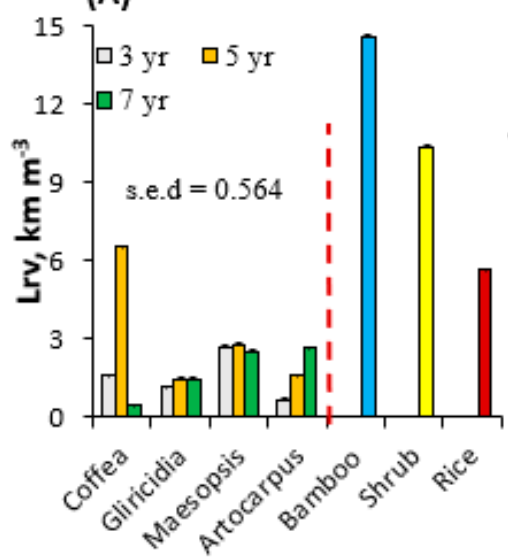

(B)

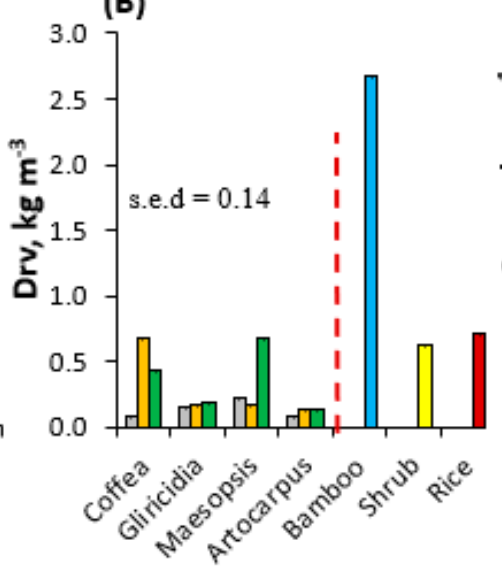

(C)

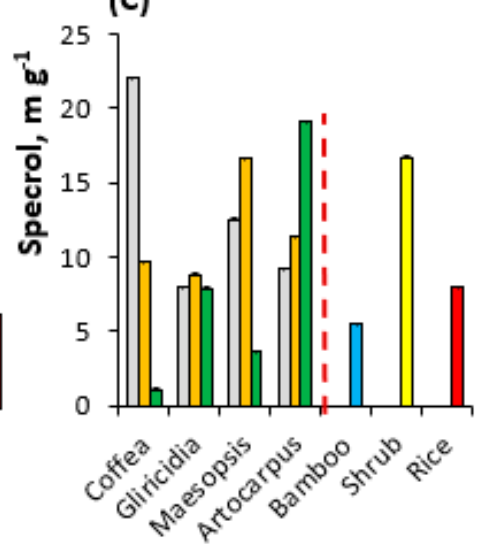

Figure 5. (A) Root length density $\left(\mathrm{L}_{\mathrm{rv}}\right)$, (B) root dry weight $\left(\mathrm{D}_{\mathrm{rv}}\right)$, and (C) specific root length $\left(\mathrm{L}_{\mathrm{rv}} / \mathrm{D}_{\mathrm{rv}}\right)$ at the topsoil layer of 0-10 cm of different tree species and non-tree species (bamboo, shrub, and rice).

The highest root biomass and root weight per unit volume of soil, $\mathrm{D}_{\mathrm{rv}}$, was found in 5-year-old coffee $\left(0.68 \mathrm{mg} \mathrm{cm}^{-3}\right)$; jackfruit had the lowest $D_{\text {rv }}$ with an average of about $0.12 \mathrm{mg} \mathrm{cm}^{-3}$ (Figure $5 \mathrm{~B}$ ). 
The specific root length (specrol $=\mathrm{L}_{\mathrm{rv}} / \mathrm{D}_{\mathrm{rv}}, \mathrm{m} \mathrm{g}^{-1}$ of roots) differed between tree species; coffee had finer roots as shown by a high specrol value of about $22 \mathrm{~m} \mathrm{~g}^{-1}$, but it declined rapidly with time to $9 \mathrm{~m} \mathrm{~g}^{-1}$ (Figure 5C); a similar case was also found in Maesopsis. Jackfruit roots, by contrast, increased in specrol with time up to $19 \mathrm{~m} \mathrm{~g}^{-1}$, while the specrol of Gliricidia was not changing with time at about $8 \mathrm{~m} \mathrm{~g}^{-1}$. Bamboo had the lowest specrol $\left(5.5 \mathrm{~m} \mathrm{~g}^{-1}\right)$.

\subsection{Soil Shear Strength}

The average soil shear strength in our measurements was 3.37 MPa (Figure 6). There appeared to be $(p=0.055)$ a significant interaction between tree species and age on soil shear strength, accompanying a significant difference between tree species. The highest soil shear strength was found in the plot with bamboo (average of $4.82 \mathrm{MPa}$ ). Soil shear strength in the bund of a paddy rice field (2.38 MPa) was higher than that for all trees tested, except for coffee.

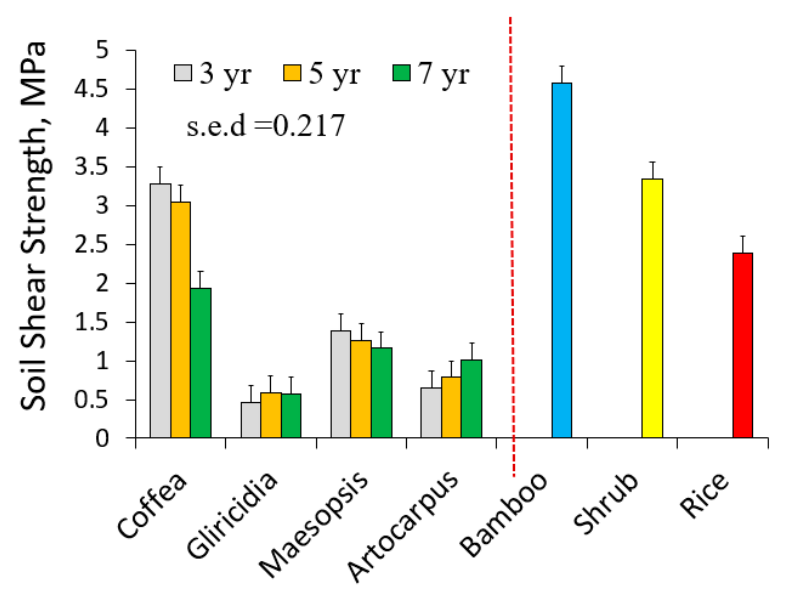

Figure 6. Soil shear strength (SS) at $5 \mathrm{~cm}$ depth for samples taken close to four species of trees and three types of non-trees.

\subsection{Soil Shear Strength in Relation to Root Length Density in the Topsoil}

The high shear strength close to bamboo stands was clearly correlated to the high root length density (Figure 7). In other trees and non-trees such relation was not clear, possibly due to the scarcity of soil samples with $\mathrm{L}_{\mathrm{rv}}$ values above $10 \mathrm{~km} \mathrm{~m}^{-3}$.

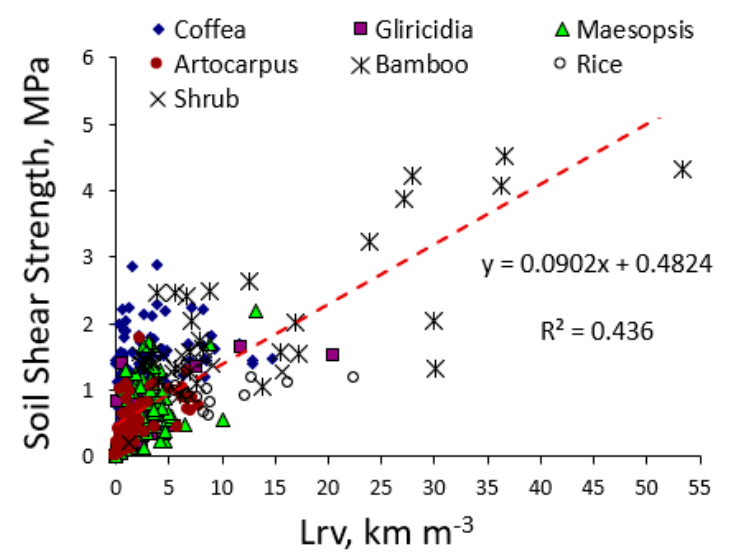

Figure 7. Regression of soil shear strength at $5 \mathrm{~cm}$ depth on root length density ( $\left.\mathrm{L}_{\mathrm{rv}}\right)$ of various plant species in the layer $0-10 \mathrm{~cm}$. 


\subsection{Allometry of Proximal Tree Root Systems}

Results of the root survey of various tree species in six locations suggested difference among locations, with proximal root diameters relative to the stem diameters high in Bangsri and low in Ngantang (Figure 8). Our data allow a partial disentangling of site (e.g., soil or climate related), species, and age effects.

(A)

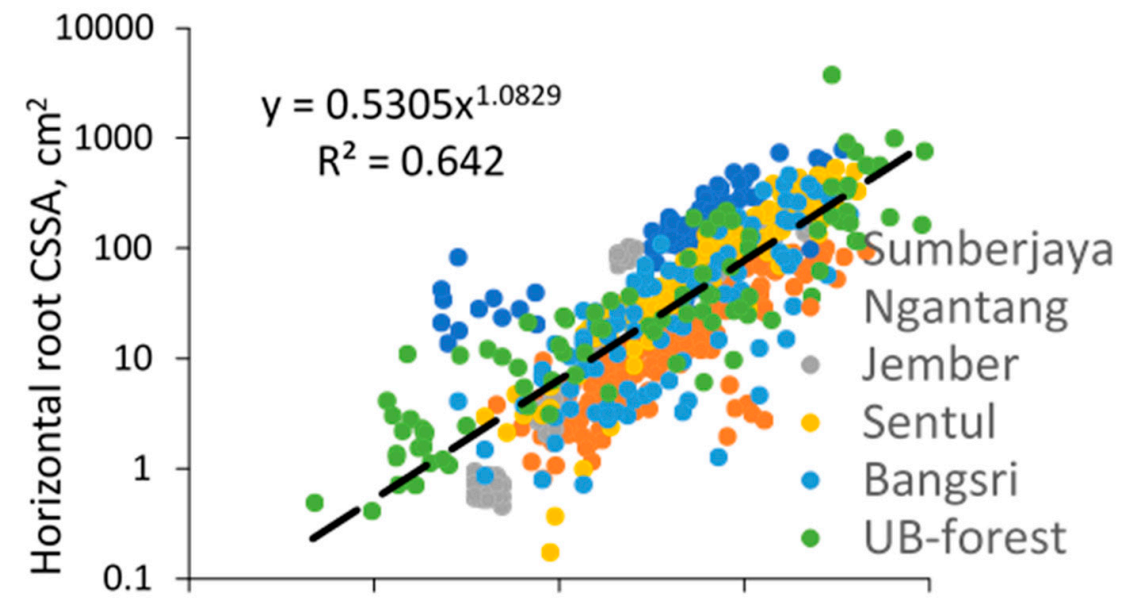

(B)

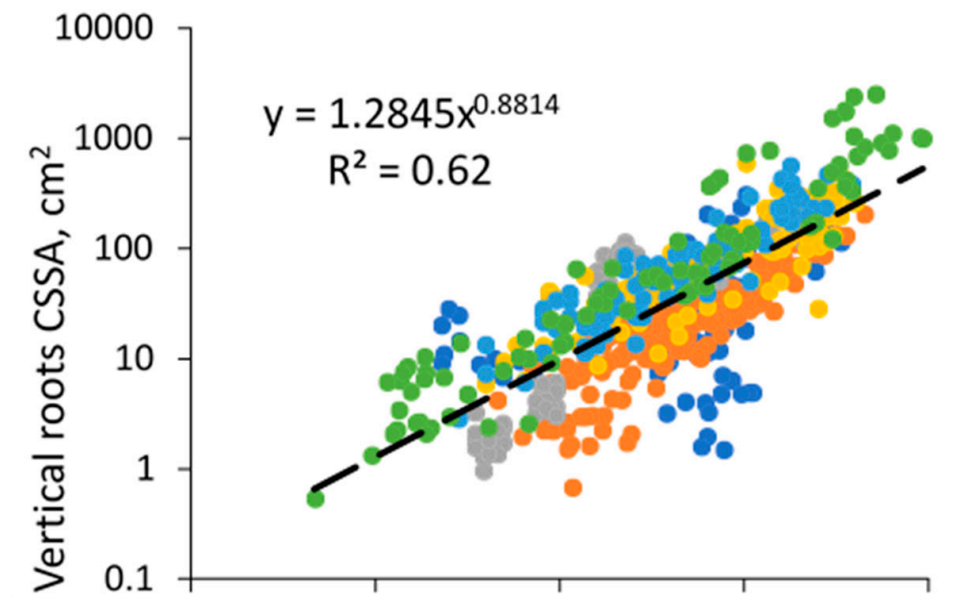

(C)

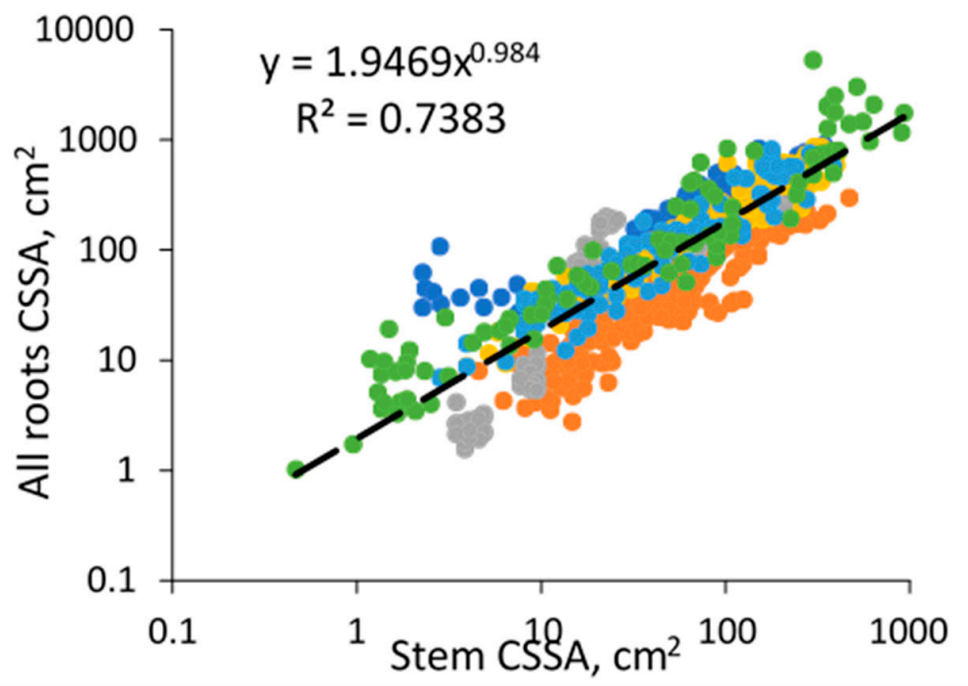

Figure 8. Relationship between cross-sectional area (CSSA) of tree stems and (A) horizontal roots $\left(\mathrm{D}_{\mathrm{h}}{ }^{2}\right)$, (B) vertical roots $\left(\mathrm{D}_{\mathrm{v}}{ }^{2}\right)$, and (C) total proximal roots for 685 tree samples of 60 tree species across five study sites. 
Across all tree observations, variation in tree diameter accounted for $74 \%$ of variation in the sum of proximal root CSSA (Figure 8 C), 62\% of variation in vertical root CSSA (Figure $8 \mathrm{~B}$ ), and $64 \%$ of variation in horizontal root CSSA (Figure 8A). Average root-to-shoot ratio in terms of CSSA was around 2.39 (mean 2.21), average IRA 1.30 (median 1.11), and average IRB 1.09 (median 0.816).

Across all species the relative importance of vertical roots decreased with increasing stem diameter, and that of horizontal roots increased, with only a slight decline in root/shoot ratio (in terms of cross-sectional area) from 1.95 to 1.74 in the observed range of tree sizes (Table 3). The ratio of vertical to horizontal roots declined from 2.42 to 0.60 , with lateral roots taking over from the tap root in most species.

Table 3. Average impact of increasing stem diameter (and cross-sectional area, CSSA) on vertical and horizontal proximal root CSSA, based on regression equations in Figure 8.

\begin{tabular}{ccccc}
\hline $\begin{array}{c}\text { Stem CSSA, } \\
\mathbf{c m}^{\mathbf{2}}\end{array}$ & $\begin{array}{c}\text { Vertical } \\
\text { (IRA) }\end{array}$ & $\begin{array}{c}\text { Horizontal } \\
\text { (IRB) }\end{array}$ & $\begin{array}{c}\text { Root/Shoot } \\
\text { CSSA }\end{array}$ & $\begin{array}{c}\text { Vertical/Horizontal } \\
\text { Ratio }\end{array}$ \\
\hline 1 & 1.28 & 0.53 & 1.95 & 2.42 \\
10 & 0.98 & 0.64 & 1.88 & 1.52 \\
100 & 0.74 & 0.78 & 1.81 & 0.96 \\
1000 & 0.57 & 0.94 & 1.74 & 0.60 \\
\hline
\end{tabular}

The ANOVA showed that tree species differed significantly $(p<0.05)$ in IRA (Index of Root Anchoring) and IRB (Index of Root Binding) values but given the overall relationship between stem diameter and both IRA and IRB values (Table 3), differences in the diameters at which tree species were observed could be (partially) responsible for this finding.

Appendix A lists the $50+$ species to which the 685 measured trees belong with, a minimum of four, a median of 9.5, an average of 12.7, and a maximum of 58 observations per tree species (with robusta coffee as most studied tree). The mean diameters per species of the observed trees had a minimum of $1.5 \mathrm{~cm}$, a median of $8.5 \mathrm{~cm}$, an average of $8.0 \mathrm{~cm}$, and a maximum of $19.9 \mathrm{~cm}$. Across all tree species, there was no significant relationship (as evident from the low fraction of variance accounted for or $R^{2}$ value) between the average stem diameter at which a species was observed, and the average IRA (or IRB) value recorded (Figure 9). We can thus assume that differences in observed IRA and IRB values between species cannot be simply attributed to the differences in stem diameters for the trees observed.

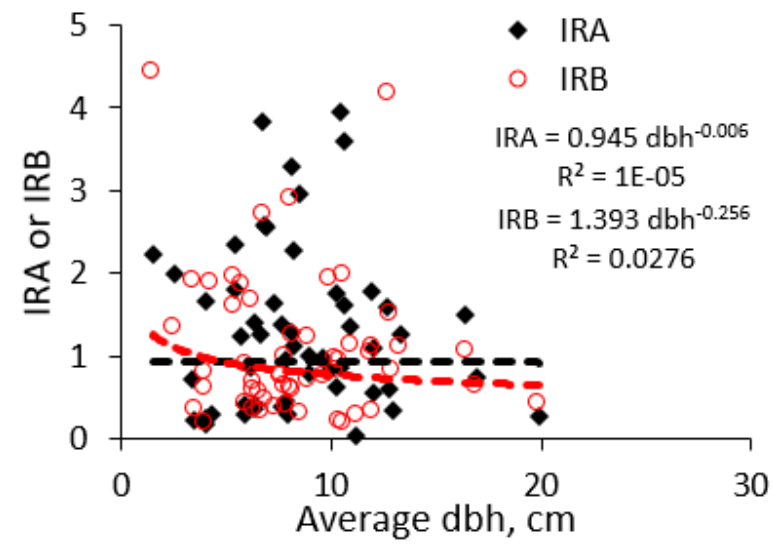

Figure 9. Relationship between average value of the IRA and IRB indices and average stem diameter at which a tree species was observed for the $50+$ tree species in the survey.

Based on the observed IRA and IRB distributions at species level (rather than at the observed tree level, as the number of observations per species was uneven), the lower and upper quartile were 0.5 and 1.8 for IRA, and 0.5 and 1.5 for IRB, respectively (Figure 10). Using these thresholds, Table 4 shows a two-way classification of the tree species observed in the survey. 

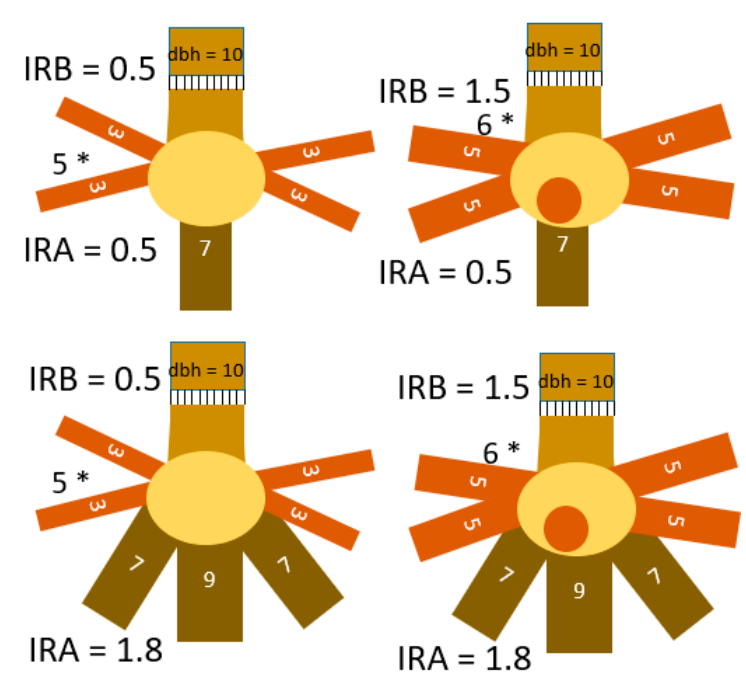

Figure 10. Examples of root-to-shoot relations at the four classification thresholds in Table 4 . The IRB for a tree with stem diameter of 10 and 6 horizontal roots of $5 \mathrm{~cm}$ diameter is $6^{*} 5^{2} / 10^{2}=1.5$, while that for a tree with 5 roots of $3.16 \mathrm{~cm}$ is $5 * 3.16^{2} / 10^{2}=0.5$.

Table 4. Two-way classification of trees based on rooting indices IRA (Index of Root Anchoring) and IRB (Index of Root Binding soil particles) classified by lower and upper quartiles of their distributions

\begin{tabular}{|c|c|c|c|}
\hline INDEX & IRB_Low $(<0.5)$ & IRB_Medium (0.5-1.5) & IRB_High (>1.5) \\
\hline $\begin{array}{l}\text { IRA_Low } \\
\quad<0.5\end{array}$ & $\begin{array}{l}\text { Mangifera indica, } \\
\text { Citrus } \times \text { sinensis, } \\
\text { Malus domestica, } \\
\text { Cassia fistula, } \\
\text { Agathis dammara, } \\
\text { Ficus benjamina, } \\
\text { Annona muricata }\end{array}$ & $\begin{array}{c}\text { Spathodea campanulata, } \\
\text { Pinus merkusii, } \\
\text { Melia azedarach, } \\
\text { Jatropha curcas, } \\
\text { Ceiba pentandra, } \\
\text { Trema orientalis }\end{array}$ & Litsea garcia \\
\hline $\begin{array}{l}\text { IRA_Medium } \\
0.5-1.8\end{array}$ & $\begin{array}{c}\text { Eucalyptus deglupta, } \\
\text { Cinnamommum burmannii }\end{array}$ & $\begin{array}{l}\text { Parkia speciosa, } \\
\text { Sandoricum koetjape, } \\
\text { Hevea brasiliensis, } \\
\text { Aleurites moluccana, } \\
\text { Durio zibethinus, } \\
\text { Erythrina subumbrans, } \\
\text { Ochroma pyramidale, } \\
\text { Syzygium polyanthum, } \\
\text { Swietenia mahagoni, } \\
\text { Persea americana, } \\
\text { Calliandra calothyrsus, } \\
\text { Pangium edule, } \\
\text { Maesopsis eminii, } \\
\text { Nephelium lappaceum, } \\
\text { Psidium guajava, } \\
\text { Toona sureni, } \\
\text { Coffea canephora var. } \\
\text { robinson, } \\
\text { Artocarpus communis, } \\
\text { Tectona grandis }\end{array}$ & $\begin{array}{l}\text { Homalantus populneus, } \\
\text { Artocarpus heterophyllus, } \\
\text { Hibiscus tiliaceus, } \\
\text { Pterocarpus indicus, } \\
\text { Paraserianthes falcataria, } \\
\text { Leucaena leucocephala, } \\
\text { Artocarpus elasticus }\end{array}$ \\
\hline $\begin{array}{l}\text { IRA_High } \\
\quad>1.8\end{array}$ & $\begin{array}{l}\text { Quercus lineata, } \\
\text { Macarangga triloba, } \\
\text { Syzygium aqueum, } \\
\text { Croton argyratus, } \\
\text { Ficus padana }\end{array}$ & $\begin{array}{l}\text { Coffea canephora } \\
\text { var. robusta, } \\
\text { Piper aduncum, } \\
\text { Gmelina arborea }\end{array}$ & $\begin{array}{l}\text { Michellia alba, } \\
\text { Coffea arabica, } \\
\text { Gliricidia sepium, } \\
\text { Senna spectabilis }\end{array}$ \\
\hline
\end{tabular}


All nine cells of Table 4 had at least one tree species, with the largest number (obviously) in the mid-range values for both IRA and IRB. The seven species in the upper left cell (low IRA and low IRB) had a low overall root-to-shoot ratio, while the four species in the lower right cell (high IRA and high IRB) a high overall one. The other cells represent a partial tradeoff between vertical and horizontal roots (or IRA and IRB values, respectively).

The two main coffee species (arabica and robusta) had a relatively high IRA value (strong taproot system), with average or high lateral root development as well (relative to stem diameters). Most of the fruit trees commonly found in coffee agroforestry (such as Artocarpus elasticus (jackfruit), Parkia speciosa (petai), and Durio zibethinus (durian)) had intermediate values for both IRA and IRB. The same holds for common timber species such as Maesopsis eminii (pohon afrika), Toona sureni (suren), Tectona grandis (teak), Swietenia mahagoni (mahogany). However, their generally larger stem diameters, relative to coffee, still imply a larger absolute contribution to vertical root development in the plot as a whole. Legume trees commonly used as shade trees in current coffee agroforestry systems, Gliricidia sepium and Senna spectabilis (ramayana), provided a higher anchoring per unit stem diameter than the more traditional shade tree, Erythrina subumbrams (dadap).

A further comparison between pruned and unpruned robusta coffee in Sumberjaya (data not shown) found the highest IRA (7.7) for unpruned coffee, suggesting that unpruned coffee is a good species for anchoring riverbanks. This characteristic disappears with pruning, confirming earlier research where frequent pruning of other tree species also led to the formation of more roots in the surface layer [56].

\section{Discussion}

All four hypotheses were confirmed in this study. The break strength of woody roots across five species was positively related to lignin and nitrogen content and negatively to polyphenol content. A linear model explained $81 \%$ of the variation (Figure 4B). Lignin content alone accounted for $70 \%$ of the variation. Mahogany (Swietenia mahogani) and coffee (Coffea canephora) had the strongest roots, gmelina (Gmelina arborea) and suren (Toona sureni) the weakest, and giant bamboo (Bambusa arundinacea) had an intermediate root strength.

Soil shear strength depends on soil texture and soil water content, and we found a considerable spread in shear strength with low root length densities (Figure 7). The only species with sufficiently high root length densities to increase shear strength was bamboo. However, our test was based on the top $10 \mathrm{~cm}$ of soil, testing a possible break at $5 \mathrm{~cm}$ depth, which is unlikely to happen. The shallow landslides of most interest would slide at depths of $30 \mathrm{~cm}$ to $1 \mathrm{~m}$. From our data it is unlikely that root length densities at such depth would be high enough to have a substantial effect on shear strength. However, as landslides are binary (yes or no) events, a small change in the threshold value may still be relevant. In terms of land use change, it is the change in root presence that matters, especially a decrease, as a preceding (forest) vegetation may have prevented landslides to occur that were otherwise 'due' (as the thickness and weight of soil layers exceeded what can be prevented from sliding by the soil properties as such). To judge absolute contributions to anchoring of the rooted soil, absolute tree size may be at least as important as the relative allocation over vertical and horizontal roots indicated by the IRA and IRB values.

The combination of root quality characteristics determining tensile strength according to our results in Figure 4 is different from that determining decomposition rate [39], although high lignin content is associated with strong and slowly decomposing roots. Tree species having specific rooting habits (high root strength and root diameter) can be used to control erosion and when linked with extreme flood probability can be used to indicate the risk of a storm likely to cause slope instability in the period between clear-felling and tree re-growth [19]. Our root tensile strength measurements of 64-478 $\mathrm{kPa}$ were lower than values reported in the literature, such as the $17.6 \mathrm{MPa}$ for woody roots of $5.5 \mathrm{~mm}$ diameter measured for Pinus radiata [24]. More measurements on larger-diameter woody roots are still needed to clarify the difference between these results. 
Trees with high IRA (Index of Root Anchoring) do not always have a low IRB (Index of Root Binding of soil particles) value or vice versa. Results in Table 4 can be interpreted as guide for suitability of trees as riverbank stabilizer. Coffee (especially without pruning) is potentially suitable for anchoring and soil surface holding at the riverbank, but it has a low root length density (Figure 5). Combination with other trees such as Gliricidia (high IRB as well as IRA) and other grasses is probably better to increase slope stability. High economic value trees (fruit and timber trees) in Sumberjaya (West Lampung) [57] are mostly grouped in the medium class (Table 4). Indeed, tree roots contribute to soil shear strength, but only in the upper $0.4 \mathrm{~m}$ of the soil. Most failures, however, occur at greater depths as anchorage by deeper roots was not effective or absent [58]. Evaluation of suitable trees for stabilizing riverbank should also consider the root strength differences [59].

Compared to other methods of observing tree root characteristics the proximal root method, based on fractal branching theory [42], allowed a much wider part of the field-level variation among sites, tree species, tree management, and tree size to be sampled, with an investment of 1-2 person-hours per tree for preparation and observation. As no roots are cut and soil can be returned to the original position the method is essentially 'non-destructive'. Among the limitations of the classification of proximal roots is that tree species with large horizontal roots may have 'sinker' roots further away from the stem that can have a major effect on strengthening the rooted soil as a whole. Root studies on Indonesian trees in the 1930s showed a wide range of rooting patterns along vertical and horizontal spread, including sinker roots [60].

A further caveat is that measurements in the dry season might be different; as all our measurements were during the rainy season. Landslide risk can be higher at the start of the rainy season (when roots are not yet fully active), as well as towards the end (when the whole soil system tends to be water-saturated).

The interest of farmers or watershed managers in deep roots for possible landslide risk reduction, may need to be balanced by considerations from the tree's perspective [61]. In terms of plant strategies, deep roots help first of all in water acquisition during dry (and sunny etc.) periods [62]. Horizontal roots provide nutrients and water during rainy seasons. It is tempting to interpret the root-to-sheet ratio in terms of cross-sectional area (and likely xylem vessel transport capacity) as a fail-safe strategy to be able to support the leaf canopy on either surface or deeper soil water, depending on conditions. Any impact on slope stabilization is at best a 'co-benefit' for the tree, not a major selection force.

Conceptually the different scales (root, tree, and vegetation) can be combined to understand landslide risk at landscape level and to target interventions to reduce risk, but a fully quantitative model that includes all relations of dynamic tree root system growth and decay along with the probability of rainfall intensities and slope geo-hydrology is not feasible at this stage. While most practices that try to reduce erosion target an increase of water infiltration [45], such increase can effectively increase landslide risk unless it is accompanied by deep and strong tree root systems. The collapse of terraces on steep slopes can be interpreted this way. Increased risk of landslides after reduction in tree cover is likely to peak once tree root system decay has reduced soil shear strength and before water infiltration into the soil profile has been reduced. Gradual replacement of trees on hill slopes, as practiced in the 'sisipan' management style of agroforests [63], will have lower risk than a clear felling-replanting. Maintaining and promoting mixed tree vegetation will reduce (but not necessarily minimize) risk, while providing other benefits to local livelihoods. Based on this study, we suggest a mix of tree species with deep roots and grasses with intense and strong fine roots will provide the highest riverbank and hillslope stability, especially if drastic tree pruning or clearing-replanting events can be avoided.

\section{Conclusions}

Our investigations confirmed that woody roots play a role in holding soil together and resisting mass movement in landslides. The critical load where individual roots break is related to the root's lignin content (its woodiness). The shear strength of a volume of soil over any plane increases proportionally with the number and strength of individual roots. With a similar overall ratio of woody root to stem 
cross sectional area, there are consistent differences between tree species in root development in the topsoil and at depth, that contribute to differences in soil binding and soil anchoring, respectively. Differences in the distribution of tree roots between species can be used to reduce landslide risks in the context of productive coffee agroforestry systems. Tree root architecture varies with species, location, and age. On average the cross-sectional area of proximal roots is twice that of the stem, with only a small reduction in the ratio with increasing stem diameter. The fraction of proximal roots in the vertical and horizontal categories varies more between species than the root-to-shoot ratio of cross-sectional areas. Using the Index of Root Anchoring (based on vertical roots) and the Index of Soil Binding (based on horizontal roots), tree species in the upper and lower quartile of each indicator were identified. However, the strong location effect that was observed implies that site-specific observations will be needed for selecting trees that are locally deep-rooted, taking current observations only as first indication. A mixed vegetation is the simplest way of ensuring that both soil binding and soil anchoring functions are provided.

Author Contributions: Conceptualization, K.H. and M.V.N; Investigation, K.H., W.W. and D.S.; Methodology, K.H., W.W., D.S. and M.V.N.; Validation, D.S.; Writing-original draft, K.H. and M.V.N.; Writing一review and editing, K.H. and M.V.N. All authors have read and agreed to the published version of the manuscript.

Funding: The Sumberjaya case study has been funded by the Australian Center for International Agricultural Research (ACIAR) through the World Agroforestry Center (ICRAF)-Southeast Asia, while the case study in Malang was funded by the Indonesian Ministry of Culture and Education (DIKTI, A2 Program). CIFOR through TroFCCA project supported our activity in Ciherang sub-watershed (Sentul, Bogor), UNDP-KLHK through CCCD Project in Bangsri sub watershed (Malang), and the work in UB Forest was supported by Rector of Brawijaya University through collaborative research UB-CEH(UK).

Acknowledgments: Ari Santosa, Mohadi Nurhada, Veronika Kurniasari, Emanuel Ardian Kristanto, Astrid Ferera, Arya Putra Widyatmadya, and Tsarwah Al Sausan offered valuable contributions during their field work as undergraduate students of University of Brawijaya, Malang. We appreciated the valuable inputs of Rachmat Mulia, Fahmuddin Agus, and Jianchu Xu to earlier drafts.

Conflicts of Interest: The authors declare no conflict of interest. The funders had no role in the design of the study; in the collection, analyses, or interpretation of data; in the writing of the manuscript, or in the decision to publish the results.

\section{Appendix A}

Table A1. Root observations across six sites, with number of trees observed (N), average dbh, IRA, and IRB, and quartiles in IRA and IRB distribution.

\begin{tabular}{ccccccc}
\hline Species & N & Dbh Avg & IRA Avg & IRB Avg & Quartile & Quartile \\
\hline Mangifera indica & 6 & 11.2 & 0.04 & 0.29 & IRA Q1 & IRB Q1 \\
Citrus × sinensis & 6 & 4.0 & 0.18 & 0.19 & IRA Q1 & IRB Q1 \\
Malus domestica & 6 & 3.5 & 0.23 & 0.36 & IRA Q1 & IRB Q1 \\
Cassia fistula & 6 & 19.9 & 0.26 & 0.42 & IRA Q1 & IRB Q1 \\
Agathis dammara & 6 & 5.9 & 0.29 & 0.43 & IRA Q1 & IRB Q1 \\
Ficus benjamina & 6 & 7.9 & 0.29 & 0.41 & IRA Q1 & IRB Q1 \\
Annona muricata & 6 & 6.3 & 0.37 & 0.35 & IRA Q1 & IRB Q1 \\
Spathodea campanulata & 6 & 4.0 & 0.25 & 0.61 & IRA Q1 & IRB Q23 \\
Pinus merkusii & 11 & 12.9 & 0.34 & 0.83 & IRA Q1 & IRB Q23 \\
Melia azedarach & 11 & 7.6 & 0.40 & 0.75 & IRA Q1 & IRB Q23 \\
Jatropha curcas & 6 & 6.3 & 0.41 & 0.68 & IRA Q1 & IRB Q23 \\
Ceiba pentandra & 6 & 5.9 & 0.41 & 0.89 & IRA Q1 & IRB Q23 \\
Trema orientalis & 10 & 7.8 & 0.47 & 0.64 & IRA Q1 & IRB Q23 \\
Litsea garcia & 5 & 4.3 & 0.30 & 1.88 & IRA Q1 & IRB Q4 \\
Eucalyptus deglupta & 6 & 12.0 & 0.56 & 0.33 & IRA Q23 & IRB Q1 \\
Cinnamommum burmannii & 10 & 7.3 & 1.65 & 0.38 & IRA Q23 & IRB Q1 \\
Parkia speciosa & 19 & 12.8 & 0.59 & 1.50 & IRA Q23 & IRB Q23 \\
Sandoricum koetjape & 20 & 10.2 & 0.62 & 0.96 & IRA Q23 & IRB Q23 \\
\hline
\end{tabular}


Table A1. Cont.

\begin{tabular}{|c|c|c|c|c|c|c|}
\hline Species & $\mathbf{N}$ & Dbh Avg & IRA Avg & IRB Avg & Quartile & Quartile \\
\hline Hevea brasiliensis & 10 & 16.9 & 0.75 & 0.64 & IRA Q23 & IRB Q23 \\
\hline Aleurites moluccana & 15 & 8.9 & 0.80 & 0.71 & IRA Q23 & IRB Q23 \\
\hline Durio zibethinus & 15 & 10.4 & 0.87 & 0.95 & IRA Q23 & IRB Q23 \\
\hline Erythrina subumbrans & 20 & 7.8 & 0.95 & 0.98 & IRA Q23 & IRB Q23 \\
\hline Ochroma pyramidale & 7 & 9.6 & 0.99 & 0.76 & IRA Q23 & IRB Q23 \\
\hline Syzygium polyanthum & 5 & 8.9 & 1.00 & 1.218 & IRA Q23 & IRB Q23 \\
\hline Swietenia mahagoni & 45 & 12.0 & 1.09 & 1.11 & IRA Q23 & IRB Q23 \\
\hline Persea americana & 21 & 8.2 & 1.13 & 1.26 & IRA Q23 & IRB Q23 \\
\hline Calliandra calothyrsus & 15 & 6.6 & 1.26 & 0.57 & IRA Q23 & IRB Q23 \\
\hline Pangium edule & 23 & 13.3 & 1.27 & 1.11 & IRA Q23 & IRB Q23 \\
\hline Maesopsis eminii & 31 & 10.9 & 1.36 & 1.14 & IRA Q23 & IRB Q23 \\
\hline Nephelium lappaceum & 32 & 7.6 & 1.37 & 0.77 & IRA Q23 & IRB Q23 \\
\hline Psidium guajava & 10 & 6.3 & 1.40 & 0.58 & IRA Q23 & IRB Q23 \\
\hline Toona sureni & 25 & 16.4 & 1.50 & 1.07 & IRA Q23 & IRB Q23 \\
\hline Coffea canephora var. robinson & 16 & 4.0 & 1.66 & 0.80 & IRA Q23 & IRB Q23 \\
\hline Artocarpus communis & 4 & 10.2 & 1.76 & 0.83 & IRA Q23 & IRB Q23 \\
\hline Tectona grandis & 9 & 11.9 & 1.79 & 1.03 & IRA Q23 & IRB Q23 \\
\hline Homalantus populneus & 5 & 3.4 & 0.73 & 1.90 & IRA Q23 & IRB Q4 \\
\hline Artocarpus heterophyllus & 35 & 9.9 & 0.82 & 1.93 & IRA Q23 & IRB Q4 \\
\hline Hibiscus tiliaceus & 20 & 6.2 & 0.86 & 1.68 & IRA Q23 & IRB Q4 \\
\hline Pterocarpus indicus & 5 & 5.7 & 1.25 & 1.86 & IRA Q23 & IRB Q44 \\
\hline Paraserianthes falcataria & 15 & 8.1 & 1.28 & 2.91 & IRA Q23 & IRB Q4 \\
\hline Leucaena leucocephala & 15 & 12.7 & 1.59 & 4.17 & IRA Q23 & IRB Q4 \\
\hline Artocarpus elasticus & 4 & 10.6 & 1.62 & 1.99 & IRA Q23 & IRB Q̄4 \\
\hline Quercus lineata & 4 & 6.9 & 2.57 & 0.48 & IRA Q4 & IRB Q1 \\
\hline Macarangga triloba & 4 & 8.5 & 2.96 & 0.30 & IRA Q44 & IRB Q1 \\
\hline Syzygium aqueum & 4 & 10.6 & 3.60 & 0.19 & IRA Q4 & IRB Q1 \\
\hline Croton argyratus & 4 & 6.7 & 3.84 & 0.34 & IRA Q44 & IRB Q1 \\
\hline Ficus padana & 4 & 10.4 & 3.96 & 0.22 & IRA Q4 & IRB Q1 \\
\hline Coffea canephora var. robusta & 58 & 2.5 & 1.99 & 1.35 & IRA Q44 & IRB Q23 \\
\hline Piper aduncum & 4 & 8.2 & 2.28 & 0.58 & IRA Q̄4 & IRB Q23 \\
\hline Gmelina arborea & 4 & 8.1 & 3.28 & 0.62 & IRA Q4 & IRB Q23 \\
\hline Michellia alba & 5 & 5.4 & 1.81 & 1.96 & IRA Q4 & IRB Q4 \\
\hline Coffea arabica & 10 & 1.5 & 2.23 & 4.43 & IRA Q4 & IRB Q4 \\
\hline Gliricidia sepium & 14 & 5.4 & 2.35 & 1.60 & IRA Q44 & IRB Q̄4 \\
\hline Acacia auriculiformis & 16 & 6.8 & 2.58 & 2.72 & IRA Q4 & IRB Q4 \\
\hline
\end{tabular}

\section{References}

1. Sidle, R.C.; Dhakal, A.S. Recent advances in the spatial and temporal modeling of shallow landslides. In Proceedings of the 2003 MODSIM Conference, Townsville, Australia, 14-17 July 2003; pp. 602-607.

2. Stokes, A.; Norris, J.E.; Van Beek, L.P.H.; Bogaard, T.; Cammeraat, E.; Mickovski, S.B.; Jenner, A.; Di Iorio, A.; Fourcaud, T. How vegetation reinforces soil on slopes. In Slope Stability and Erosion Control: Ecotechnological Solutions; Springer: Dordrecht, The Netherlands, 2008; pp. 65-118.

3. Van Noordwijk, M.; Hairiah, K.; Lasco, R.; Tata, H.L. How can agroforestry be part of disaster risk management. In Sustainable Development through Trees on Farms: Agroforestry in Its Fifth Decade; Van Noordwijk, M., Ed.; World Agroforestry (ICRAF): Bogor, Indonesia, 2019; pp. 215-229.

4. Pohl, M.; Alig, D.; Körner, C.; Rixen, C. Higher plant diversity enhances soil stability in disturbed alpine ecosystems. Plant Soil 2009, 324, 91-102. [CrossRef]

5. Alam, S.; Banjara, A.; Wang, J.; Patterson, W.B.; Baral, S. Novel Approach in Sampling and Tensile Strength Evaluation of Roots to Enhance Soil for Preventing Erosion. Open J. Soil Sci. 2018, 8, 330. [CrossRef]

6. Giadrossich, F.; Schwarz, M.; Cohen, D.; Cislaghi, A.; Vergani, C.; Hubble, T.; Phillips, C.; Stokes, A. Methods to measure the mechanical behaviour of tree roots: A review. Ecol. Eng. 2017, 109, 256-271. [CrossRef]

7. Iverson, R.M. Landslide triggering by rain infiltration. Water Resour. Res. 2000, 36, 1897-1910. [CrossRef] 
8. Micheli, E.R.; Kirchner, J.W. Effects of wet meadow riparian vegetation on streambank erosion. 2. Measurements of vegetated bank strength and consequences for failure mechanics. Earth Surf. Process Landf. 2002, 27, 687-697. [CrossRef]

9. Roering, J.J.; Schmidt, K.M.; Stock, J.D.; Dietrich, W.E.; Montgomery, D.R. Shallow landsliding, root reinforcement, and the spatial distribution of trees in the Oregon Coast range. Can. Geotech. 2003, 40, 237-253. [CrossRef]

10. Wu, T.H.; Swanston, D.N. Risks of landslides in shallow soils and its relation to clearcutting in Southeastern Alaska. For. Sci. 1980, 26, 495-510. [CrossRef]

11. O'Loughlin, C.L.; Watson, A.J. Root wood strength deterioration in radiate pine after clearfelling. N. Z. J. For. Sci. 1979, 9, 284-293.

12. Wilkinson, P.L.; Anderson, M.G.; Lloyd, D.M. An integrated hydrological model for rain-induced landslide prediction. Earth Surf. Processes Landf. 2002, 27, 1285-1297. [CrossRef]

13. Ziemer, R.R.; Swantson, D.N. Root Strength Changes after Logging in Southeast Alaska; USDA Forest Service Research Note PNW; Department of Agriculture, Forest Service, Pacific Northwest Forest and Range Experiment Station: Portland, OR, USA, 1997; Volume 306.

14. Abe, K.; Ziemer, R.R. Effect of Tree Roots on Shallow-Seated Land Slides; USDA Forest Service Gen. Tech. Rep. PSW-GT130; International Union of Forestry Research: Vienna, Austria, 1991; pp. 11-20.

15. Schiechtl, H.M. Bioengineering for Land Reclamation and Conservation; University of Alberta Press: Edmonton, AL, Canada, 1980.

16. Shen, P.; Zhang, L.M.; Chen, H.X.; Gao, L. Role of vegetation restoration in mitigating hillslope erosion and debris flows. Eng. Geol. 2017, 216, 122-133. [CrossRef]

17. Wang, B.; Zhang, G.H. Quantifying the binding and bonding effects of plant roots on soil detachment by overland flow in 10 typical grasslands on the Loess Plateau. Soil Sci. Soc. Am. J. 2017, 81, 1567-1576. [CrossRef]

18. Zhu, J.; Wang, Y.; Wang, Y.; Mao, Z.; Langendoen, E.J. How does root biodegradation after plant felling change root reinforcement to soil? Plant Soil 2020, 446, 211-227. [CrossRef]

19. Watson, A.; Phillips, C.; Marden, M. Root strength, growth, and rates of decay: Root reinforcement changes of two tree species and their contribution to slope stability. Plant Soil 1999, 217, 39-47. [CrossRef]

20. Hubble, T.C.T.; Docker, B.B.; Rutherfurd, I.D. The role of riparian trees in maintaining riverbank stability: A review of Australian experience and practice. Ecol. Eng. 2010, 36, 292-304. [CrossRef]

21. Bischetti, G.B.; Chiaradia, E.A.; Simonato, T.; Speziali, B.; Vitali, B.; Vullo, P.; Zocco, A. Root Strength and Root Area Ratio of Forest Species in Lombardy (Northern Italy). Plant Soil 2005, 278, 11-22. [CrossRef]

22. De Baets, S.; Poesen, J.; Reubens, B.; Wemans, K.; De Baerdemaeker, J.; Muys, B. Root tensile strength and root distribution of typical Mediterranean plant species and their contribution to soil shear strength. Plant Soil 2008, 305, 207-226. [CrossRef]

23. Abernethy, B.; Rutherfurd, I.D. The distribution and strength of riparian tree roots in relation to riverbank reinforcement. Hydrol. Processes 2001, 15, 63-79. [CrossRef]

24. Ekanayake, J.C.; Marden, M.; Watson, A.J.; Rowan, D. Tree roots and slope stability: A comparison between Pinus radiata and kanuka. N. Z. J. For. Sci. 1997, 27, 216-233.

25. Genet, M.; Kokutse, N.; Stokes, A.; Fourcaud, T.; Cai, X.; Ji, J.; Mickovski, S. Root reinforcement in plantations of Cryptomeria japonica D. Don: Effect of tree age and stand structure on slope stability. For. Ecol. Manag. 2008, 256, 1517-1526. [CrossRef]

26. Tosi, M. Root tensile strength relationships and their slope stability implications of three shrub species in the Northern Apennines (Italy). Geomorphology 2007, 87, 268-283. [CrossRef]

27. Giadrossich, F.; Cohen, D.; Schwarz, M.; Ganga, A.; Marrosu, R.; Pirastru, M.; Capra, G.F. Large roots dominate the contribution of trees to slope stability. Earth Surf. Processes Landf. 2019, 44, 1602-1609. [CrossRef]

28. Collison, A.J.C.; Anderson, M.G. Using a combined slope hydrology/stability model to identify suitable conditions for landslide prevention by vegetation in the humid tropics. Earth Surf. Processes Landf. 1996, 21, 737-747. [CrossRef]

29. Nilaweera, N.S.; Nutalaya, P. Role of tree roots in slope stabilisation. Bull. Eng. Geol. Environ. 1999, 57, 337-342. [CrossRef] 
30. Madsen, C.; Potvin, C.; Hall, J.; Sinacore, K.; Turner, B.L.; Schnabel, F. Coarse root architecture: Neighbourhood and abiotic environmental effects on five tropical tree species growing in mixtures and monocultures. For. Ecol. Manag. 2020, 460, 117851. [CrossRef]

31. Danjon, F.; Reubens, B. Assessing and analyzing 3D architecture of woody root systems, a review of methods and applications in tree and soil stability, resource acquisition and allocation. Plant Soil 2008, 303, 1-34. [CrossRef]

32. Collison, A.; Pollen, N. The effects of riparian buffer strips on streambank stability: Root reinforcement, soil strength and growth rates. In Roots and Soil Management: Interaction between Roots and the Soil; Zobel, R.W., Wright, S.F., Eds.; American Society of Agronomy: Madison, WI, USA, 2005; Volume 48, pp. 15-56.

33. Reubens, B.; Poesen, J.; Danjon, F.; Geudens, G.; Muys, B. The role of fine and coarse roots in shallow slope stability and soil erosion control with a focus on root system architecture: A review. Trees 2007, 21, 385-402. [CrossRef]

34. Stokes, A.; Atger, C.; Bengough, A.G.; Fourcaud, T.; Sidle, R.C. Desirable plant root traits for protecting natural and engineered slopes against landslides. Plant Soil 2009, 324, 1-30. [CrossRef]

35. Boldrin, D.; Leung, A.K.; Bengough, A.G. Root biomechanical properties during establishment of woody perennials. Ecol. Eng. 2017, 109, 196-206. [CrossRef]

36. Chen, H.; Harmo, M.E.; Griffiths, R.P. Decomposition and nitrogen release from decomposing woody roots in coniferous forests of the Pacific Northwest: A chronosequence approach. Can. J. For. Res. 1999, 31, 246-260. [CrossRef]

37. Schroth, G. Decomposition and nutrient supply from biomass. In Trees, Crops and Soil Fertility: Concepts and Research Methods; Schroth, G., Sinclair, F.L., Eds.; CABI Publishing: Wallingford, UK, 2003; pp. 131-150.

38. Hairiah, K.; Sulistyani, H.; Suprayogo, D.; Widianto Purnomosidhi, P.; Widodo, R.H.; Van Noordwijk, M. Litter layer residence time in forest and coffee agroforestry systems in Sumberjaya, West Lampung. For. Ecol. Manag. 2006, 224, 45-57. [CrossRef]

39. Palm, C.A.; Sanchez, P.A. Nitrogen release from some tropical legumes as affected by lignin and polyphenol contents. Soil Biol. Biochem. 1991, 23, 83-88. [CrossRef]

40. Genet, M.; Stokes, A.; Salin, F.; Mickovski, S.B.; Fourcaud, T.; Dumail, F.; van Beek, R. The Influence of Cellulose Content on Tensile Strength in Tree Roots. Plant Soil 2005, 278, 1-9. [CrossRef]

41. Van Noordwijk, M.; Purnomosidhi, P. Root architecture in relation to tree-soil- crop interactions and shoot pruning in agroforestry. Agrofor. Syst. 1996, 30, 161-173. [CrossRef]

42. Van Noordwijk, M.; Mulia, R. Functional branch analysis as tool for scaling above- and belowground trees for their additive and non-additive properties. Ecol. Model. 2002, 149, 41-51. [CrossRef]

43. Schwarz, M.; Lehmann, P.; Or, D. Quantifying lateral root reinforcement in steep slopes-From a bundle of roots to tree stands. Earth Surf. Processes Landf. J. Br. Geomorphol. Res. Group 2010, 35, 354-367. [CrossRef]

44. Nespoulous, J.; Merino-Martin, L.; Monnier, Y.; Bouchet, D.C.; Ramel, M.; Dombey, R.; Viennois, G.; Mao, Z.; Zhang, J.L.; Cao, K.F.; et al. Tropical forest structure and understorey determine subsurface flow through biopores formed by plant roots. Catena 2019, 181, 104061. [CrossRef]

45. Van Noordwijk, M.; Agus, F.; Verbist, B.; Hairiah, K.; Tomich, T.P. Managing Watershed Services in Ecoagriculture Landscapes. In Farming with Nature: The Science and Practice of Ecoagriculture; Scherr, S.J., McNeely, J.A., Eds.; Island Press: Washington, DC, USA, 200; pp. 191-212.

46. Burroughs, E.R.; Thomas, B.R. Declining Root Strength in Douglas-Fir after Felling as a Factor in Slope Stability; US Department Agriculture Forest Services Research Paper INT-190; Department of Agriculture, Forest Service, Intermountain Forest and Range Experiment Station: Ogden, UT, USA, 1977.

47. Ziemer, R.R. An apparatus to measure the crosscut shearing strength of roots. Can. J. For. Res. 1978, 8, 142-144. [CrossRef]

48. Walkley, A.; Black, I.A. An examination of the Degtjareff method for determining soil organic matter, and a proposed modification of the chromic acid titration method. Soil Sci. 1934, 37, 29-38. [CrossRef]

49. Goering, H.K.; Van Soest, P.J. Forage Fiber Analysis; Agricultural Handbook no 379; USDA: Washington, DC, USA, 1970; p. 20.

50. Anderson, J.M.; Ingram, J.S.I. Tropical Soil Biology and Fertility: A Handbook of Methods; CAB. International: Wallingford, UK, 1989; p. 171.

51. Rose, C. An Introduction to the Environmental Physics of Soils, Water and Watershed; Cambridge University Press: Cambridge, UK, 2004; p. 65. 
52. Tennant, D. A test of a modified line intersect method of estimating root length. J. Ecol. 1975, 63, 995-1001. [CrossRef]

53. Payne, R.W.; Lane, P.W.; Ainsley, A.E.; Bicknell, K.E.; Digby, P.G.N.; Harding, S.A.; Leech, P.K.; Simpson, H.R.; Todd, A.D.; Verrier, P.J.; et al. Genstat 5 Reference Manual; Clarendon Press: Oxford, UK, 1987.

54. Van Noordwijk, M. Functional branch analysis to derive allometric equations. In Modelling Global Change Impacts on the Soil Environment: Report of Training Workshop 5-13 May 1998; IC-SEA Report No., 6; Murdiyarso, D., van Noordwijk, M., Suyamto, D.A., Eds.; BIOTROP-GCTE: Bogor, Indonesia; ICSEA: Lisbon, Portugal, 1999; pp. 77-80.

55. Akinnifesi, F.K.; Rowe, E.C.; Livesley, S.J.; Kwesiga, F.R.; Van Lauwe, B.; Alegre, J.C. Tree root architecture. In Below-Ground Interactions in Tropical Agroecosystems. Concepts and Models with Multiple Plant Components; Van Noordwijk, M., Cadisch, G., Ong, C.K., Eds.; CABI Publishing: Wallingford, UK, 2004; pp. 61-82.

56. Hairiah, K.; Widianto, W.; Utami, S.R.; Sunaryo, D.S.; Sitompul, S.M.; Lusiana, B.; van Noordwijk, M.; Cadish, G. Pengelolaan Tanah Masam Secara Biologi: Refleksi Pengelaman dari Lampung Utara; World Agroforestry Centre (ICRAF): Bogor, Indonesia, 2000; p. 184.

57. Budidarsono, S.; Wijaya, K. Praktek Konservasi dalam Budidaya Kopi Robusta dan Keuntungan Petani. Agrivita 2004, 26, 107-117.

58. Cammeraat, E.; van Beek, R.; Kooijman, A. Vegetation succession and its consequences for slope stability in SE Spain. Plant Soil 2005, 278, 135-147. [CrossRef]

59. Stokes, A.; Mattheck, C. Variation of wood strength in tree roots. J. Exp. Bot. 1996, 47, 693-699. [CrossRef]

60. Coster, C. Wortelstudien in de tropen. V. Gebergtehoutsoorten [Root studies in the Tropics. V. Tree species of the mountain region]. Tectona 1935, 28, 861-878.

61. Van Noordwijk, M.; Lawson, G.; Hairiah, K.; Wilson, J. Root Distribution of Trees and Crops: Competition and/or Complementarity. Tree-Crop Interactions: Agroforestry in a Changing Climate; CABI: Wallingford, UK, 2015; pp. 221-257.

62. Van Noordwijk, M.; Martikainen, P.; Bottner, P.; Cuevas, E.; Rouland, C.; Dhillion, S.S. Global change and root function. Glob. Change Biol. 1998, 4, 759-772. [CrossRef]

63. Wibawa, G.; Hendratno, S.; van Noordwijk, M. Permanent smallholder rubber agroforestry systems in Sumatra, Indonesia. In Slash and Burn: The Search for Alternatives; Palm, C.A., Vosti, S.A., Sanchez, P.A., Ericksen, P.J., Juo, A.S.R., Eds.; Columbia University Press: New York, NY, USA, 2005; pp. 222-232. 